\title{
Designing Train Passenger Seat by Kansei Engineering in Indonesia
}

\author{
Sakya Nabila Hapsari $1^{1}{ }^{*}$, Teddy Sjafrizal ${ }^{1}$, and Rino Andias Anugraha ${ }^{1}$ \\ ${ }^{1}$ Telkom University, School of Industrial Engineering, Industrial Engineering Department, \\ Jl.Telekomunikasi Terusan Buah Batu, 40247 Bandung, Indonesia
}

\begin{abstract}
Public transport adoption is still major problem in Indonesia. Integrating impression and emotion to service may change the image of public transport, leading to fast adoption rate. As product development technique, Kansei Engineering is well known to facilitate that integration. This paper communicates the implementation of Kansei Engineering (KE) in designing train passenger seat in Indonesia. The train between BandungSolo ( 8 hours journey) was chosen to be the investigated object. The train was selected to be refurbished by introducing a new passenger seat design, emphasizing on the improvement of passenger experience. As the first step of KE type I technique, travel experience of the existing passengers were taken into the consideration for selecting Kansei words. It was found that the relevant Kansei words to design passenger train seat in Indonesia were: comfort, people-friendly, multifunction, safe, soft, spacious, relaxing, superior, maintainable, strong, producible, minimalist, attractive, modern, unique, and durable. Upon understanding the semantic meaning of those words, physical properties and technical specification were produced by consulting to the related members. Finally, a passenger seat with synthetic leather cover, modular design, foldable table, individual power point, bluesilver color, and adjusted to Indonesian's anthropometry data was proposed as the final design
\end{abstract}

\section{Introduction}

Congested traffic is one of the chronic issues of major cities with high density population. This phenomenon is getting serious at the emerging countries. Idea of pushing people to use public transport is believed to be the solution for reducing the road congestion [1] However, asking people to use public transport involves converting the habit.

Habit to use public transport is built up by the society and flourished by the perception towards the travelling mode [2]. Social push and the good image of public transport accelerate the conversion. Thus, designing the service to the society requires people-centred perspective from different groups of users [3]. In system-level design, some values are considered as the importance to form the consumer perceptions and preferences through product appearance communication: aesthetic, symbolic, functional, ergonomic, attentiondrawing and categorization value [4].

\footnotetext{
*Corresponding author: sakyahapsari@gmail.com
} 
Appearance of product is the first thing attracts customer attentions. Having a product with attractive esthetical value results in high likelihood of buying. Esthetical and impression gained by the customers at the first sight drive their attention to buy the product/service. Functional value may come in the reliability and durability of the product/service. Ergonomic value ensures the product/service to deliver the comfort, effective, efficient, safe, and healthy design. Packaging condition is the example of attention-drawing value. Unique food packaging draws more attention. Finally, customers have the ability to categorize the product based on those values above. All these values determine the likelihood of potential customers to own the product/services.

In public transport, people-centered perspective in designing the service could be derived from travel experience. Travel experience determines the loyalty of passenger in taking public transport. Study on bus passengers perspectives suggest that bus provider or travel agent shall considering travel experience prior to launching the service [5]. Study by [6] identifies seven dimensions of experience factor: individual space, information provision, staff's skills, social environment, vehicle maintenance, off-board facilities, and ticket line service. In addition, the attitudes toward the standard quality level of public transport fluctuate across the passenger socio-economics groups, including gender [7]. Therefore, the product/service development process of public transport shall have the capability to process experience factor. It can be fulfilled by deploying Kansei Engineering techniques.

Established by the Japanese, Kansei Engineering (KE) has become one of the powerful approach in developing ergonomics consumer-oriented products by considering the interaction between human-machine system, environment and the society [8]. KE combines both functional and emotional aspect of the user needs as the quality level to be achieved [9]. Successful KE stories are best delivered by the product of Mazda, the Miata; the goodup Bra made by Wacoal and the Sharps's liquid Crystal viewCAM [8]. Other success stories were reported on the house design[10] \& costume [11], packaging industry[12], aviation interior[13], e-commerce [14] office furniture [15] and many more.

$\mathrm{KE}$ unites the aspect of emotion and feeling through engineering process. KE has widely used for many kinds of product development and it becomes more complex. By the technology advancement, there are at least 4 types of KE techniques [4]. KE type I focuses on identification and development of product strategy and market segment into a tree structure that represents the manual way connection of customer's affective needs and product properties. KE Type II frequently uses computer aided system in a form of interference engines and Kansei databases, therefore Kansei and product properties are connected using mathematical statistical tools. Type III utilizes mathematical modelling in proposing design solution. Lastly, type IV has the ability to visualize and interact with the design by adopting virtual reality technology. Among those types, KE type I is believed to be the most versatile technique since it requires less resources.

This communication describes the adoption of KE type I in public transport, especially train. Previous study on the experience factor requirements of public transport (e.g. bus) finds that safety, waiting time and body comfort are the most important and requires to perform in high performance [5]. Unlike body comfort, safety and waiting time are not purely decided by the design. Since sitting on the passenger seat is the most frequent activities during travelling by bus or train, body comfort is heavily determined by seat design. Therefore, seat design was taken as the object to be investigated for the study of KE in public transport especially in the train. Additionally, outcomes of KE for public transport of one region may result in different outcomes for other regions. It is due to the fact that the needs, impression, experience and expectation of users are different towards public transport. Thus, study on deploying KE type I for designing train passenger seat in a region is unique and reasonable. Additionally, to the knowledge of authors, there is 
research gap on the study of KE type I for passenger train in Indonesia. Hence, this study aimed to explore and describe the deployment of KE type I at Indonesia's train service especially for designing the passenger seat.

\section{Kansei engineering techniques}

The implementation of KE follows the structural method that has been proven in several studies [5,10,12,14,16-19]. Generally, the method may be modified or replaced based on certain purposes. Here is the generic structure of KE [4]:

- Choice of Participant Groups

The selection of participant group members may come from different people with similar behaviour in using the certain product. Since the KE needs the homogenous subjects to perform the implementation, the information of this criteria can be gained from the company or experts who have studied about market segmentation. This information is collected not in context of $\mathrm{KE}$, but it may be used anytime as the input for $\mathrm{KE}$ implementation.

- Collection of Kansei Words

Kansei Words are the group of words that describes the product properties. In common, these words are adjective or grammatical form. It can be collected from any reliable sources, such as literatures, magazines, experts, manuals, experienced users, or related Kansei studies. The Kansei Words should be collected in a range of 50-600 words until no new words occur, therefore it has to be checked by dictionary.

- Data reduction methods

Reduction of Kansei Words is useful to find the proper number of Kansei Words, as it may have poor quality because of the error from the participants or it does not suitable to the number of participants. In order to solve this problem, there are two empirical tests that commonly used for data reduction, which are validity test and factor analysis. The validity test comes from the questions of design importance degrees, while the factor analysis comes from semantic differential evaluation that measuring how the Kansei Words corresponding to the product.

- Rating-scale Types used

There are two types of rating-scale types that commonly used in KE, which are Visual Analogue Scale (VAS) and Likert scale. Likert scale is easier and more common to use. It has three types of scales, which are five-Likert scales, seven-Likert scales, and nine-Likert scales.

- Connecting the Kansei Words to product properties

Every Kansei Word can generate the product properties, therefore it becomes the most important step of Kansei Engineering. The ways of connecting the Kansei Words to product properties are executed qualitatively or quantitatively. The qualitative way performs the Kansei Words connection based on the intuition that cannot be communicated easily as it is done in Quality Function Deployment (QFD), furthermore this way is commonly used in Kansei Engineering Type 1. Meanwhile, the quantitative way utilizes statistical tools, such as neural networks algorithm [20], fuzzy logics[21], rough set analysis [22] and some other tools.

KE type I has been applied in several industries [4]. The legendary example of implementation of KE type I was performed by Mazda for its vehicle interior design. Intimate and lifestyle product such the brassiere design of Wacoal was designed by utilizing KE type I. Extended beyond Japanese industries and products, it is recorded that KE type I was also implemented in packaging industry in UK [12] and sunglasses e-commerce in Malaysia [14]. Having said so, the idea of taking KE type I to be implemented at the designing process of Indonesian's passenger train seat is very reasonable. 
The framework covered in Kansei Engineering Type 1 are divided into several steps, which are as follows [4] :

Table 1. Steps of Kansei Engineering type I

\begin{tabular}{|c|c|}
\hline Steps & Characteristics \\
\hline $\begin{array}{l}\text { Step 1: } \\
\text { Identification of Target }\end{array}$ & $\begin{array}{l}\text { - Determine targeted customer } \\
\text { - Gather customer's Kansei words } \\
\text { - Extensively apply marketing research and expert judgment }\end{array}$ \\
\hline $\begin{array}{l}\text { Step 2: } \\
\text { Determination of Product } \\
\text { Concept }\end{array}$ & $\begin{array}{l}\text { - Deciding product concept to be further developed. } \\
\text { - Considering customer interaction with the concept }\end{array}$ \\
\hline $\begin{array}{l}\text { Step 3: } \\
\text { Breaking Down The Product } \\
\text { Concept }\end{array}$ & $\begin{array}{l}\text { - Assigning physical characteristics. } \\
\text { - KJ method (affinity diagram) could be applied }\end{array}$ \\
\hline $\begin{array}{l}\text { Step 4: } \\
\text { Deployment to Physical Design } \\
\text { Characteristics }\end{array}$ & $\begin{array}{l}\text { - Able to relate concept to technical words } \\
\text { - May end up in deciding the physical characteristics such as } \\
\text { size, appearance design, color and function. }\end{array}$ \\
\hline $\begin{array}{l}\text { Step 5: } \\
\text { Translation to Technical } \\
\text { Specifications }\end{array}$ & $\begin{array}{l}\text { - Specification is defined, consultation with the expert or lead } \\
\text { users are likely. }\end{array}$ \\
\hline
\end{tabular}

\section{Procedures}

This descriptive study was implemented on the train passenger seat design of PT.KAI (Indonesian Railway Company). As many as 96 respondents were questioned by interviewing techniques for refining the Kansei Words. Validity and reliability testing were performed on the gathered Kansei Words. They were performed by distributing questionnaires to the respondents to measure the degree of importance for each Kansei Words by five Likert scales. The results were developed as the input for Spearman-Rho validity test and Cronbach Alpha reliability test. Subsequently, semantic differential evaluation was performed by pairing the Kansei Words with the antonyms and questioned those pairs by the questionnaire using five Likert scales. Factor analysis is helpful to direct the process of concept mapping by clustering the Kansei Words into the smaller groups [4]. The analysis was done with the support of Kaiser-Meyer-Olkin (KMO) and Bartlett's Test and Principal Component Analysis (PCA), then the results were further analysed by identifying the clusters or factors. KJ method was performed by using affinity diagram, in which the result of factor analysis was proceeded by giving the name of each cluster or factors based on the relationship to Kansei Words. Upon clustered, the Kansei words were processed further to realize the product concept. The concept mapping was accomplished using the tree structure that contains several levels of Kansei Words. It started from zerolevel Kansei Word, which is defined as the name of cluster in this research. The following levels contain the Kansei Words, semantic meaning, metrics, physical properties, and technical specification. Thus, seat technical specification could be derived upon discussion with the reliable source (company). Finally, the proposed passenger seat design was visualized. 


\section{Results and Discussion}

\subsection{Identification of target market}

The development of passenger train seat was conducted by Rolling Stock Engineering, a division of PT KAI. This division is responsible for developing the transportation of goods and passengers. The role of this division aligns with PT KAI product development strategy. The company has decided to perform convergence of three passenger train classes (Executive-Business-Economy) into two classes (Executive-New Economy). Specifically, this direction has consequences for the change of the new train class interior concept which is expected to increase the quality compared to the previous one. Change at the old class interior concept is expected to be represented by a change in the concept of the seat that can create new impression of travel experience during the train journey. This strategy is aimed to increase efficiency and competitive advantage of PT KAI in the next few years.

In order to facilitate the discussion of seat design for new train class development, the constraint of trip duration was determined. The case study concerned at long distance train, such as Kereta Api Bandung-Solo which has 8 hours-long trip. This selection was done based on the data of passenger number that exceeds other trains for each semester, which indicates the high needs of using Bandung-Solo service line.

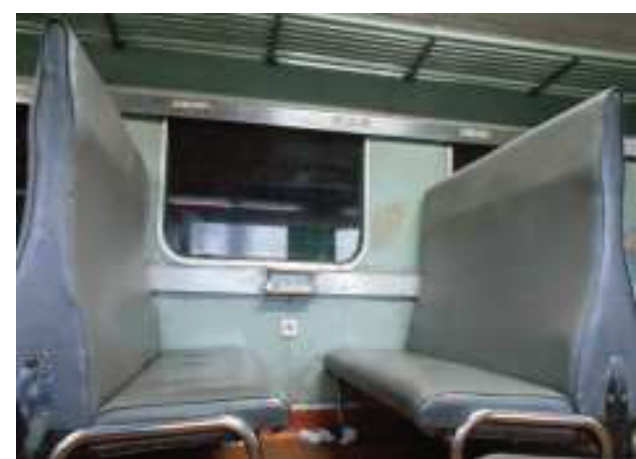

(A)

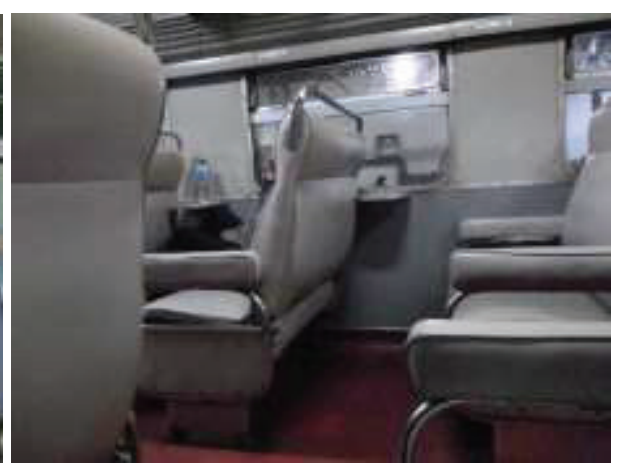

(B)

Fig. 1. (A) Current design of economy class (B) Current design of business class.

\subsection{Determination of product concept}

Below steps are critical and to be considered as the main process of KE. The steps were started from collecting Kansei Words, ensuring the validity and reliability of the words by appropriate statistical tools, applying semantic differentiation technique to understand the impression of the respondents on each Kansei Words upon reviewing seat design, and finally clustering the Kansei Words to the product matrices.

\subsubsection{Collection of Kansei words}

Kansei Words collected in this study are related to the general impression or functions represented by a train seat, either through magazines, literatures, corporate strategies, and train users. Kansei Words amount collected was 50-60 words. Words that are synonymous, then it would only have one word that is most relevant to the semantic context of the need 
for train seats. This resulted in a reduction process into 19 Kansei Words, as shown in the following table.

Upon gathering the Kansei Words, feedback from respondents were compiled to understand the validity and reliability. After 96 people were available (confidence level: 95\%, variance: 1.25 and error margin: $5 \%$ ) as respondents, feedback in the form of questionnaires of importance degree were developed. The questions were mainly to ask the importance level of each words in designing passenger train seat from the perspective of users. There were 19 closed questions contained Kansei Words, then the answers were represented by five levels of Likert Scale. This result was then processed further by validity and reliability test.

Spearman Rank Validity test was selected as the validity test. It is necessary to check the relevancy of Kansei Words for the purpose of designing the new passenger seat. The relevancy is expressed by the correlation between each value of Kansei Words with the total value of all variables. By using the alpha value $(\alpha)$ of 0.05 and number of 96 respondents, the correlation coefficient of each Kansei Words shall be more than 0.201 (critical values of Spearman's Rank table). Result in Table 2 showed that there was no correlation coefficient that less than 0.201 , therefore all Kansei Words was decided as valid and appropriate to be synthesized in the following steps of Kansei Engineering.

Once deciding all Kansei Words as valid, reliability test were conducted to ensure the consistency of those words. Following the common cut off criteria for measuring reliability, results of Cronbach Alpha for each Kansei Words must exceed or equal to 0.7 [23]. Fortunately, all the Kansei Words were believed to be reliable based on the value of Cronbach Alpha (refer to table 2 for more details). Finally, the selected Kansei Words were valid and reliable as the words representing the impression/feeling/emotion of passengers in passenger seat design.

Table 2. Spearman rank validity and Cronbach alpha

\begin{tabular}{|c|l|c|c|}
\hline No & \multicolumn{1}{|c|}{$\begin{array}{c}\text { Kansei } \\
\text { Words }\end{array}$} & $\begin{array}{c}\text { Correlation } \\
\text { Coefficient }\end{array}$ & $\begin{array}{c}\text { Cronbach } \\
\text { Alpha }\end{array}$ \\
\hline 1 & Comfort & 0.261 & 0.747 \\
\hline 2 & $\begin{array}{l}\text { People- } \\
\text { friendly }\end{array}$ & 0.492 & 0.738 \\
\hline 3 & Multifunction & 0.579 & 0.736 \\
\hline 4 & Safe & 0.452 & 0.742 \\
\hline 5 & Viable & 0.663 & 0.732 \\
\hline 6 & Soft & 0.338 & 0.741 \\
\hline 7 & Spacious & 0.578 & 0.736 \\
\hline 8 & Relaxing & 0.555 & 0.736 \\
\hline 9 & Superior & 0.711 & 0.727 \\
\hline 10 & Maintainable & 0.673 & 0.734 \\
\hline
\end{tabular}

\begin{tabular}{|c|l|c|c|}
\hline No & $\begin{array}{c}\text { Kansei } \\
\text { Words }\end{array}$ & $\begin{array}{c}\text { Correlation } \\
\text { Coefficient }\end{array}$ & $\begin{array}{c}\text { Cronbach } \\
\text { Alpha }\end{array}$ \\
\hline 11 & Light & 0.728 & 0.724 \\
\hline & & & \\
12 & Strong & 0.691 & 0.733 \\
\hline 13 & Producible & 0.784 & 0.727 \\
\hline 14 & Minimalist & 0.768 & 0.723 \\
\hline 15 & Attractive & 0.728 & 0.729 \\
\hline 16 & Colorful & 0.466 & 0.734 \\
\hline 17 & Modern & 0.588 & 0.734 \\
\hline 18 & Unique & 0.573 & 0.729 \\
\hline 19 & Durable & 0.617 & 0.736 \\
\hline
\end{tabular}

\subsubsection{Semantic differentiation}

KE was invented by recognizing the semantic meaning of mentioned words as the actualization of the hidden feelings and emotions[24]. The previous steps were focused on identifying the impression/feeling/emotion of user towards the passenger seat, whereas semantic differentiation stages were taken to understand the realization of the impression/feeling/emotion on product design [25,26]. According to [4], SD evaluation is useful to study words as a scale in term of semantic space by preparing the antonyms of each Kansei Words. The antonyms are necessary to be checked first by help of dictionary or thesaurus. The evaluation was constructed through a questionnaire with the same number 
of respondents in the previous test. In order to help the respondents to answer the questionnaire, product samples of similar train passenger seat were attached. The answers were represented by the scale and they would be analyzed using factor analysis in the next step.

Table 3. Questionnaire form for semantic differentiation analysis

\begin{tabular}{|l|l|l|}
\hline Comfort & $1---$ 2---3----4---5 & Discomfort \\
\hline People-friendly & $1----2---3---4---5$ & People-unfriendly \\
\hline Multifunction & 1 ---2---3---4---5 & Single function \\
\hline Safe & $1---2---3---4---5$ & Dangerous \\
\hline Viable & $1---2---3---4---5$ & Impractical \\
\hline Soft & $1---2---3---4---5$ & Hard \\
\hline Spacious & $1---2---3---4---5$ & Narrow \\
\hline Relaxing & $1---2---3---4---5$ & Distressing \\
\hline Superior & $1---2---3---4---5$ & Inferior \\
\hline Maintainable & $1---2---3---4---5$ & Not maintainable \\
\hline Light & $1---2---3---4---5$ & Heavy \\
\hline Strong & $1---2---3---4---5$ & Brittle \\
\hline Producible & $1---2---3---4---5$ & Not producible \\
\hline Minimalist & $1---2---3---4---5$ & Lavish \\
\hline Attractive & $1---2---3---4---5$ & Boring \\
\hline Colorful & $1---2---3---4---5$ & Plain \\
\hline Modern & $1---2---3---4---5$ & Conventional \\
\hline Unique & $1---2---3---4---5$ & Common \\
\hline Durable & $1---2---3---4---5$ & Temporary \\
\hline
\end{tabular}

To be reliable for further analysis, the answers of 96 respondents were further evaluated for reliability by Kaiser-Meyer-Olkin (KMO) test and Barlett's test. KMO value states the adequacy of sample size, whereas the Barlett's test of sphericity determines the significant level of interrelationship between variables.

Table 4. Reliability result by Kaiser-Meyer-Olkin (KMO) test and Barlett's test

\begin{tabular}{|l|l|}
\hline Kaiser-Meyer-Olkin test of sampling adequacy & 0.772 \\
\hline Barlett's test of sphericity & 0.000 \\
\hline
\end{tabular}

The common acceptable cut-off criterion for KMO test is 0.50 [27,28]. Test result showed that the KMO value fulfilled the condition that the sample set was adequate and might proceed to factor analysis process. By having value of 0.772 this adequacy of the data is considered as moderate [27]. Subsequently, the data were then tested by Barlett's test for understanding the interrelationship with the concept of passenger seat design. Bartlett test sphericity result was 0.000 (significant level of $p<.05$ ). Thus, it was decided to the decision of rejecting significant interrelationship between variables affecting the concept of passenger seat design. At last, Both KMO test result and Barlett's test result permitted for further PCA process.

KMO and Bartlett's Test was proceeded by Principal Component Analysis (PCA). It may lead to clustering the Kansei Words into smaller groups. It was started from understanding the communalities value. The extraction value of communalities becomes the interpretation of how Kansei Word explain the factors. For example, the Kansei Word 
"comfort" had communalities value of 0.725 , meaning that the word "comfort" had an ability to explain the factor as much as $72.5 \%$. If the value exceeds 0.5 or $50 \%$, the Kansei Words can strongly explain the factors or exist within specific factors [28].

Table 3. Communalities Analysis Results

\begin{tabular}{|c|c|c|c|}
\hline Kansei Words & $\begin{array}{l}\text { Extraction } \\
\text { Value }\end{array}$ & Kansei Words & $\begin{array}{l}\text { Extraction } \\
\text { Value }\end{array}$ \\
\hline Comfort & 0.725 & Light & 0.497 \\
\hline People-friendly & 0.637 & Strong & 0.649 \\
\hline Multifunction & 0.606 & Producible & 0.536 \\
\hline Safe & 0.606 & Minimalist & 0.682 \\
\hline Viable & 0.391 & Attractive & 0.554 \\
\hline Soft & 0.644 & Colorful & 0.403 \\
\hline Spacious & 0.559 & Modern & 0.555 \\
\hline Relaxing & 0.601 & Unique & 0.584 \\
\hline Superior & 0.556 & Durable & 0.613 \\
\hline Maintainable & 0.617 & & \\
\hline
\end{tabular}

${ }^{*}$ items highlighted should not be taken into account $(<0.50$ cut-off criterion).

Result of communalities analysis is shown by table X. Since the majority of Kansei Words reached the value of $>0.5$, it indicated that the respondents were able to correlate the seat design impression with the Kansei Words. Nevertheless, It was found that the word "viable", "light", and "colorful" became the Kansei Words which had extraction value $<0.5$, thus they were not necessary to be taken into account those words in clustering and further steps in KE. Hence, there were 16 Kansei words that were believed to be necessary as design consideration of train passenger seat.

As these adjective were gathered based on the customers experience as train passenger, it is believed that this result may be correlate to the experience factor of bus passenger. Correlation between the findings of study by [29] on experience factors of bus passengers with the Kansei words of train passenger seat is shown by figure 1. Majority of the identified Kansei Words are related to the experience factor, especially the one that related to design. However, out of 16 Kansei Words, there are 4 words that are not related to the experience factors. "Multi-function", "minimalist" and "attractive" are believed to be unique to product design, whereas "producible" has both users and producer interest.

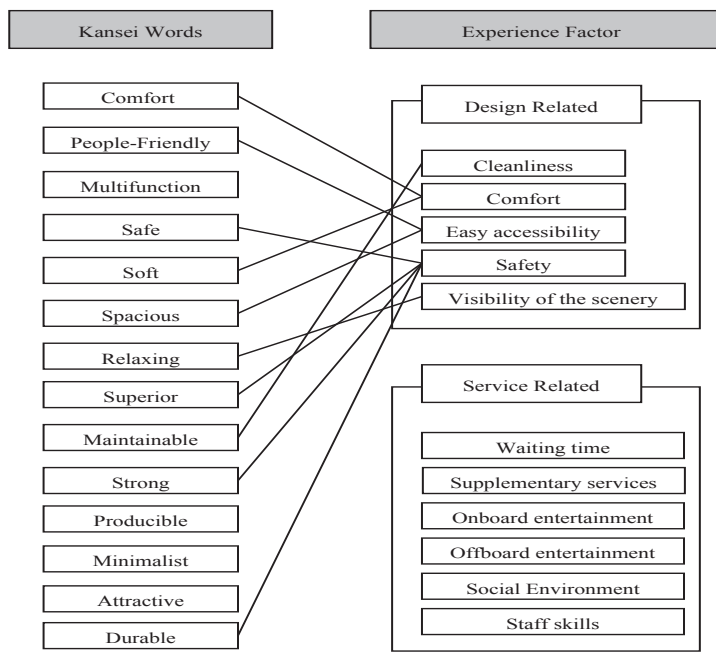

Fig. 3. Correlation between Kansei Words and Experience Factor of [31] 
After considering the communalities, the PCA was expanded to orthogonal rotation by varimax technique. Varimax is considered as the most widely method for orthogonal rotation [27,28] In term of identifying the exact cluster for each Kansei Words, it can be indicated by the value of factor loading of each cluster or component. For example, if one Kansei Word has highest loading factor in component 1, it means that this Kansei Word is categorized in component 1 , and so the other Kansei Words.

Table 4. Correlation Matrix\& Loading Factor (rotation method: Orthogonal, Varimax)

\begin{tabular}{|l|c|c|c|c|c|}
\hline \multirow{2}{*}{ Kansei Words } & \multicolumn{5}{|c|}{ Clusters/Components/Factors } \\
\cline { 2 - 6 } & $\mathbf{1}$ & $\mathbf{2}$ & $\mathbf{3}$ & $\mathbf{4}$ & $\mathbf{5}$ \\
\hline Comfort & 0.038 & -0.04 & 0.065 & 0.847 & -0.019 \\
\hline People-friendly & -0.026 & 0.085 & 0.715 & 0.039 & 0.342 \\
\hline Multifunction & 0.231 & 0.204 & 0.223 & -0.134 & 0.665 \\
\hline Safe & 0.087 & 0.451 & -0.12 & 0.402 & 0.468 \\
\hline Soft & -0.217 & 0.152 & 0.46 & 0.602 & -0.023 \\
\hline Spacious & 0.267 & -0.047 & 0.681 & 0.133 & -0.066 \\
\hline Relaxing & 0.287 & 0.248 & 0.549 & 0.019 & -0.079 \\
\hline Superior & 0.298 & 0.425 & 0.517 & -0.069 & -0.117 \\
\hline Maintainable & 0.117 & 0.767 & 0.106 & 0.05 & 0.012 \\
\hline Strong & 0.358 & 0.617 & -0.125 & 0.341 & 0.089 \\
\hline Producible & 0.448 & 0.536 & 0.211 & 0.03 & 0.056 \\
\hline Minimalist & 0.735 & 0.287 & 0.184 & 0.002 & -0.156 \\
\hline Attractive & 0.715 & 0.156 & 0.061 & -0.027 & 0.12 \\
\hline Modern & 0.651 & 0.096 & 0.209 & -0.058 & -0.273 \\
\hline Unique & 0.688 & -0.185 & 0.155 & -0.086 & 0.211 \\
\hline Durable & 0.314 & 0.703 & 0.098 & 0.091 & -0.045 \\
\hline
\end{tabular}

${ }^{*}$ The highest loading factor on each Kansei Words is highlighted

Table 4 shows the correlation matrix of the Kansei Words and the components/clusters. There were 5 components identified in this analysis. Each cluster had at least two Kansei Words that may represent the expected impression of passengers towards that cluster.

\subsection{Determination of product concept}

In the previous step, factor analysis has been developed in order to lead the step of making product concept. Since the analyzed Kansei Words were classified into five groups, it was necessary to give the name for each group. According to [4] , KJ method is the best method to collect the amount of data into groupings based on natural relationships. It uses affinity diagram as the tool to group each Kansei Words into specific categories, called affinity cluster. In this context, the relationship among the Kansei Words is shown by the score of loading factor in factor analysis. Study by [29] proposes the affinity diagram of Kansei Words in designing a product. Referring to that finding and with some adjustment, the identified clusters were named accordingly.

Table 5. Clusters naming by KJ method

\begin{tabular}{|l|lll|l|l|}
\hline Clusters/Factors & Degree & Impression & Spatial & Easy & Pleasure \\
\hline \multirow{4}{*}{ Kansei Words } & Maintainable & Minimalist & $\begin{array}{l}\text { People- } \\
\text { friendly }\end{array}$ & Multifunction & Comfort \\
\cline { 2 - 5 } & Producible & Attractive & Spacious & Safe & Soft \\
\cline { 2 - 4 } & Strong & Modern & Relaxing & & \\
\cline { 2 - 4 } & Curable & Unique & Superior & & \\
\hline
\end{tabular}



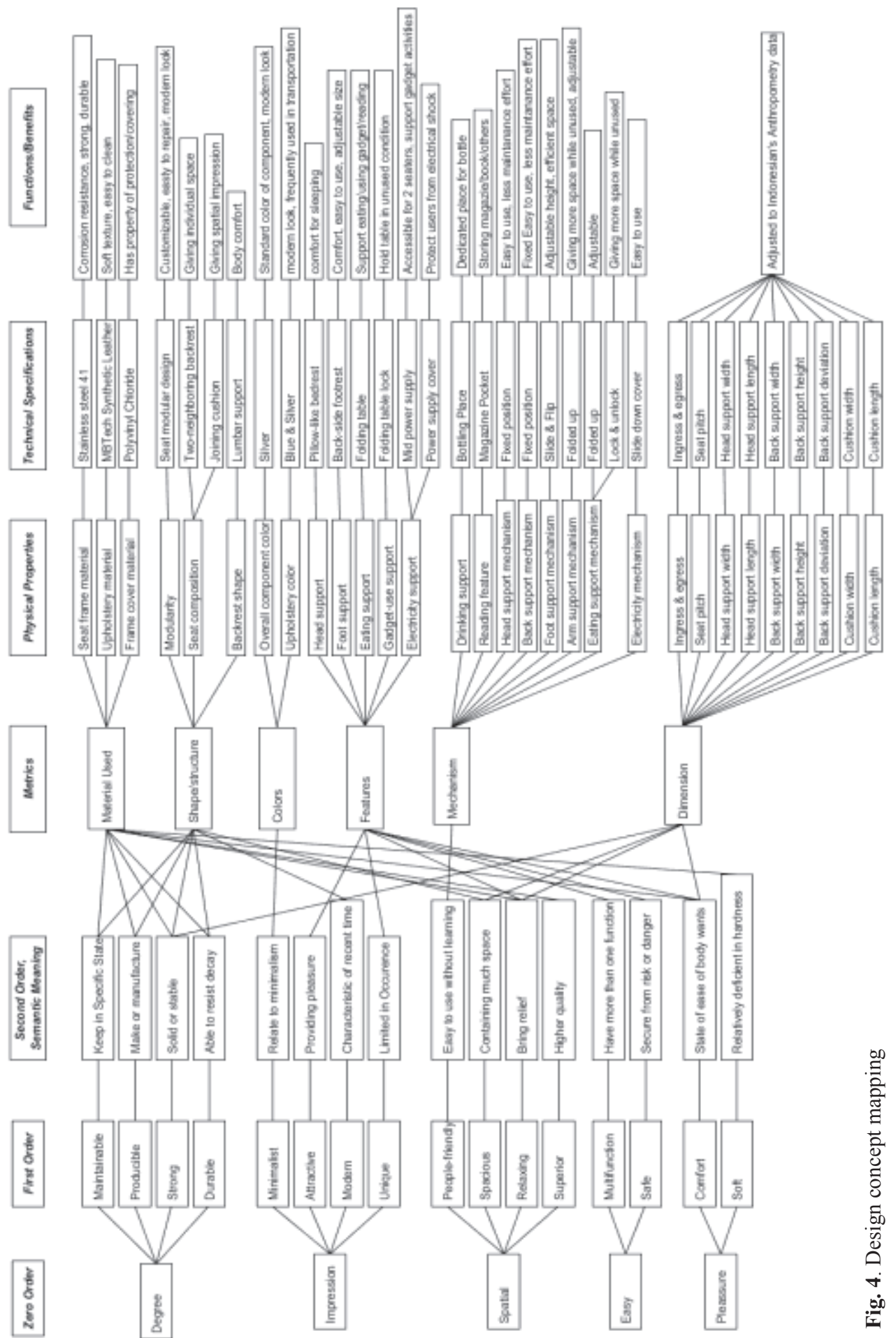
Once clustered Kansei Words were formed, the design concept mapping could be executed. Fig. 4 describes the design concept mapping result. It was started from defining the semantic definitions of each Kansei Words. Subsequently, each Kansei Word was connected to its physical product attributes. Material, shape or structure, colors, features, mechanism and dimension are considered as the common physical product attribute to be addressed for physical product development. One Kansei Words with one defined semantic meaning had at least one relationship to the product attribute.

\subsection{Deployment of physical design characteristics}

The adjective of Kansei Words and the product attributes were linked to the related design components of the passenger seat. This process was performed together with the company representatives, since they could act as the expert as well as the lead users. The translating process is described as below.

From the physical product attributes of "colors", it had "minimalist" as the related Kansei Word. Hence, for defining the physical design characteristic, any part that had function to portray minimalist impression from its color projection were designed accordingly. For this case, there were 2 items identified, "overall component color" and "upholstery color". The colors of these 2 items were selected from any color with impression of "minimalist". If there were more than one related Kansei Words, all words were considered in deciding the physical design characteristics. Similar processes were implemented on each physical design characteristic.

\subsection{Translation into technical specifications}

At last, in order to come up with proposed design, the physical design characteristics were required to be translated to technical specifications. In other words, technical specification are the understanding of product attributes from engineering perspective. The functions, mechanism, needs and condition as defined in the physical design characteristics were translated to the relevant engineering terms. The translating process is described as below.

Previously, "minimalist" was defined to be applicable to the color of "overall component color" and "upholstery color". At this stage, the color was defined accordingly. Upon discussion and considering some information in the public domain, it was concluded to select blue and silver as the color to represent "minimalist". Each of the physical design characteristics had at least one technical specification. Finally, since the technical specifications have been defined in the concept mapping, it should be visualized as the concept design.

Once the design was visualized, it was be examined for design validation. In many cases, the validation is done by questioning potential customers for acceptance. Fortunately, the company representatives acted as the expert and lead users, hence their decision were use as design acceptance decision

\section{Summary and recommendations}

Designing passenger train seat by applying Kansei engineering type I has been achieved. The proposed design was succeed in translating consumers' impressions/feeling/emotions towards passenger train set. A passenger seat with synthetic leather cover, modular design, foldable table, individual power point, blue-silver colour, and adjusted to Indonesian's anthropometry data was concluded as the proposed design. Those specifications were gathered upon considering the Kansei Words. The identified Kansei Words are comfort, 
people-friendly, multifunction, safe, soft, spacious, relaxing, superior, maintainable, strong, producible, minimalist, attractive, modern, unique, and durable. Statistically, the 16 identified Kansei Words are valid and reliable.

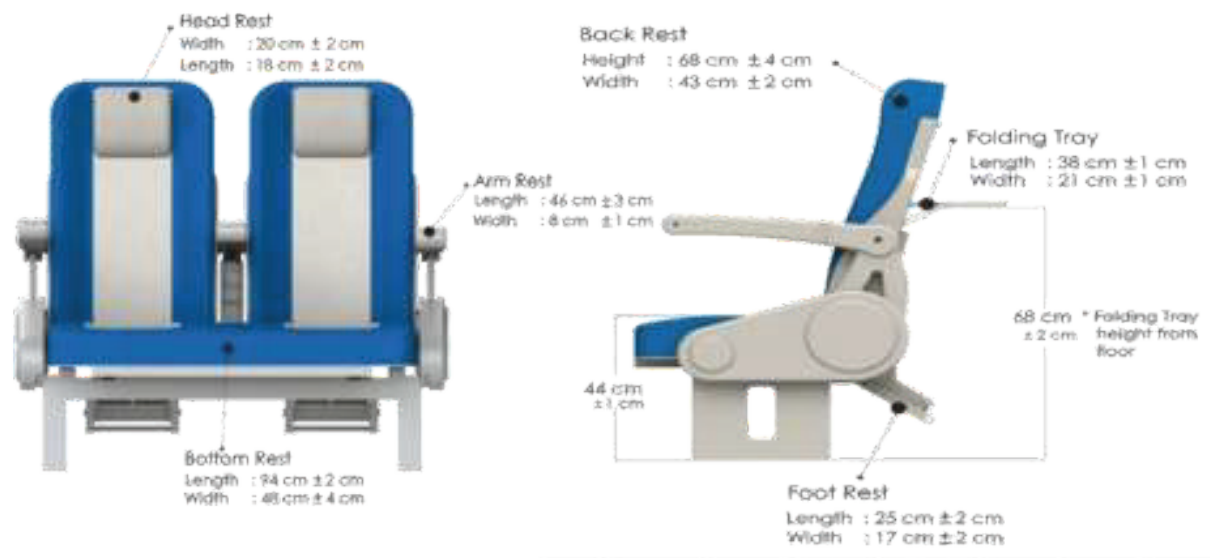

Fig. 5. Visualization of the proposed train passenger seat

The outcomes of this study may become the reference for similar studies in the future. Since, perception in travel experience may be developed by value and norms of the regions, user emotions toward public transport design may differ by location [2]. The study may be extended to other public services provided by the local government. It is also recommended to broaden similar studies to e-government service. The experience of users in using previous e-system influences their adoption to the new e-service [30]. Moreover, particularly in a multi-cultural and multi-racial society, the expectation and needs that are developed by the values and norms could be captured by deploying Kansei Engineering technique.

\section{References}

1. Federal Highway Administration, Traffic Congestion and Reliability: Linking Solutions to Problems (2017)

2. N. Klein, Urban Stud. 1 (2016)

3. L. Li and B. P. Y. Loo, Cities 58, 50 (2016)

4. M. Nagamachi and A. M. Lokman, Innovations of Kansei Engineering (2011)

5. R. Carreira, L. Patrício, R. N. Jorge, and C. L. Magee, J. Eng. Des. 24, 738 (2013)

6. R. Carreira, L. Patrício, R. Natal Jorge, and C. Magee, Transp. Policy 31, 35 (2014)

7. C. Morton, B. Caulfield, and J. Anable, Case Stud. Transp. Policy 4, 199 (2016)

8. M. Nagamachi, Ergon. Des. 10, 5 (2002)

9. A. Lanzotti, P. Tarantino, A. Lanzotti, and P. Tarantino, TQM J. 20, 324 (2008).

10. S. Ishihara, T. Matsubara, M. Nagamachi, and Y. Matsubara, Adv. Human-Computer Interact. 2011, (2011)

11. M. Nagamachi, 1999 IEEE International Conference on Systems, Man, and Cybernetics 


$$
\text { 6, } 273 \text { (1999) }
$$

12. C. Barnes, T. Childs, B. Henson, and S. Lillford, TQM J. 20, 372 (2008)

13. J. Guerin, Sixt. Symp. Qual. Funct. Deploy. 8 (2004)

14. N. K. Chuan, A. Sivaji, M. M. Shahimin, and N. Saad, Procedia - Soc. Behav. Sci. 97, 707 (2013)

15. J. Park and S. H. Han, Int. J. Ind. Ergon. 34, 31 (2004)

16. M. Nagamachi, Int. J. Ind. Ergon. 15, 3 (1995)

17. B. Razza and L. C. Paschoarelli, Procedia Manuf. 3, 6228 (2015)

18. S. Schütte and J. Eklund, Appl. Ergon. 36, 557 (2005)

19. C. Tanoue, K. Ishizaka, and M. Nagamachi, Int. J. Ind. Ergon. 19, 115 (1997)

20. S. Ishihara, K. Ishihara, M. Nagamachi, and Y. Matsubara, Int. J. Ind. Ergon. 15, 13 (1995)

21. Y. Shimizu and T. Jindo, Int. J. Ind. Ergon. 15, 39 (1995)

22. M. Nagamachi, Rough Sets and Current Trends in Computing, 27 (2006)

23. C. E. Lance, M. M. Butts, and L. C. Michels, Organ. Res. Methods 9, 202 (2006)

24. S. Schütte, Designing Feelings into Products (2002)

25. S. H. Hsu, M. C. Chuang, and C. C. Chang, Int. J. Ind. Ergon. 25, 375 (2000)

26. C. Llinares and A. F. Page, Landsc. Urban Plan. 87, 247 (2008)

27. A. S. Beavers, J. W. Lounsbury, J. K. Richards, S. W. Huck, G. J. Skolits, and S. L. Esquivel, Prat. Assesment, Res. Eval. 18, (2013)

28. A. Yong and S. Pearce, Tutorials Quant. Methods 9, 79 (2013)

29. A. M. Lokman and K. A. Kamaruddin, 2010 International Conference on User Science Engineering, 38 (2010)

30. D. Witarsyah, T. Sjafrizal, M. F. M. Fudzee, and M. A. Salamat, Int. J. Adv. Sci. Eng. Inf. Technol. 7, (2017)

31. R. Carreira, L. Patrıcio, R. Natal Jorge, C. Magee, and Q. Van Eikema Hommes, Transp. Policy 25, 233 (2013) 